\title{
競泳における腕振り型スタートに 関する分析的研究
}

\author{
佐々 木敏 (北星学園女子短期大学) \\ 波 多 野 军 郎 (東京学芸大学) \\ （昭和52年 8 月11日 受付）
}

\section{Analysis of Arm Swing Style Start in Racing Swim}

\author{
Tsutomu Sasaki* \\ Yoshiro Hatano**
}

\begin{abstract}
In order to point out certain suggestions useful in skill instruction of diving action in racing swim, the bodily action was analyzed upon taking a $16 \mathrm{~mm}$ movie. The findings may be summerised as follows;

1) During the "get set" moment, placing the center of gravity high and close to the front edge of the starting table would give some advantages for the swimmer.

2) At the moment when knees are flexed maximally during the starting action, placing the center of gravity close to the front edge of the starting table is advised.

3) Exertion of strong enough power in explossively extending the knees and hips from the point when these two joints are flexed maximally would be the key for the effective diving action.

4) The direction of take-off is often suggested to be slightly upward. While the major factor to determine this direction lies in the extension action of knees and hips, the snapping action at the ankle joint seems also to have some implication in controlling the direction of take-off.

5) Hyperextention of body during the flight after take-off may be acceptable, if the body is maintained reasonably straight at the moment of body entering into water.

(Tsutomu Sasaki and Yoshiro Hatano: Analysis of Arm Swing Style Start in Racing Swim. Jap. J. Phys. Educ., Vol. 23, No. 1, May, 1976, pp. 25 33).
\end{abstract}

* Hokusei Gakuen Junior College, Chuo-ku, Sapporo (064)

** Tokyo Gakugei University, Koganei City Tokyo (184) 


\section{1.}

体育やスポーツの場面で行われる技術指導にお いては，実際に遂行された動作を観察し，その動 作の欠点を指摘したり，より有効な動きを求めた りするという方法が一般に行われている。この場 合には，指導者の視觉が大きな武器となること は，むしろ当然であろ5．しかし，実際の身体怔 運そのものは，動きが速い例が多く，それだけに 身体各部の動作を確実に把握するのは必ずしも容 易ではない，特定の運動種目やその動作に関し て，特に鋭い観察眼を持つ限られた数の熟練者や 指導者のみが，優れた技術指導者の条件を満たす といら傾向が存在する. しかし実際の指学者の全 てがこの条件を具備しているわけではなく，更に 数多くの連動種目を取り扱わなければならない学 校体育では, 全ての種目について，同等の水隼に まで精通することを期待するのは難事であると思 われる。

ある動作や技術の特性が，視觉的に具体化でき るよらな指導のポイントが用意されていること が，指導者にとって極めて有用であるのは，まさ に上述のよ5な背景があるからである，事実，現 在では, 各種の教育機器が進歩し, 映画やビデオ テープなどを具備した教育機関も数多い。

以上のよ5な観点から，競泳に扣けるスタート 動作の技術指導上のポイントのいくつかを摘出す ることを目的として，映像分析法を用いて一連の 実験を試みたので，その結果を報告する。

\section{2. 文献}

競泳に拈けるとびこみ動作について 分析的興味 を示した初期の人に A.W. Gray がいる(1). 能率 的なとびこみの要素として彼は

（1）腕の振りとともに離陸時に加えられる 脚の キック,

(2) 力の作用する角度,

（3）能率的な入水に有効な空中姿勢, をあげ，特に放物体の原理から望ましい重心軌跡 について論じている。そして，ワイズミューラー の投射角度を $15^{\circ}$ 程度と想定し，この近辺の投射 角が有利であるはずだが，それは映画分析によっ
で时らかになると結んでいる。

その後, C.W. Maglischo はスタート動作にお ける肪の振り方を，单振動型，回転型，省略型の 3 つに分類し，それそれの飛びこみについて報告 している20). その結果, 回転型の方が単振動型の ものより, 最初の $5 \mathrm{~m}$ については有利であると述 ベている.

その他，スタート動作の各運動局面での表現に は，かなりの差異が認められる。

構えの努勢については，睩は自由に届伸できる 程度にまげる1)，軽くまげる10,21)，90にまげる2， 12)，などと示され，体幹は直角に近い角度にまげ

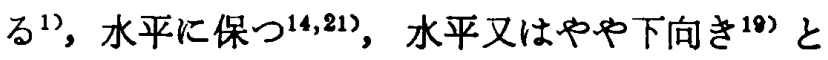

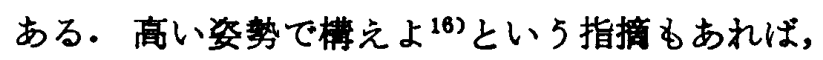
睩を十分にまげよりとい5記述もある．腕は後方 に"1)，自然な位置 ${ }^{10)}$ ，前方に下げる ${ }^{18)}$ とある。目 については，下に向ける(19)，対岸を見る(4)，まっす 〈゙前方 ${ }^{17}$ ，やや前方 ${ }^{18)}$ 見るのが良いとされ，頭 の位置についてす解釈は多様である.しかし，体 重を親指の付け根部分にかけるよ5にする7,14,21) とい5点についてはよく一致している。

とび出しまでの動作については，腕を後方に振 クつつ身体を前方にのめらせ，それからキック動 作に入る ${ }^{10,19,21)}$ こ方指摘されているが，その時 の細部の動きに関する記述は少ない。

とび出しから空中にかけての動作では，全身を 一直線になるよ5に伸ばす10,14, 18, 19,27)ことが前方 への回転を㧕えるとされているが，一方，流線型 とい5表現2,6,18,16) るみられる。角度に関して

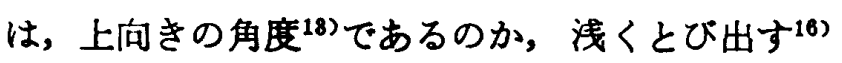
のが良いのか意見が分かれている。

入水に関しては，指先 $2,8,16,17,21)$ 中頭部 ${ }^{18,14)}$ が先 きに水を切るべきか，全身が同時に水面に当る ${ }^{19}$ のがよいのかも議論の余地がある・水面への入射 角も $\left.\left.5^{\circ} \sim 10^{\circ}, 1 i\right) 15^{\circ}, 7,18\right) 30^{\circ}$, 18) とい5数字がある 一方，小柄な選手は遠くへ浅く入るのが良い26) あ言われている. むっとも，これらの数字は入水 時に身体が水面となす角度であるのか，重心軌跡 に拈ける入射角であるのかは注意深く検討しなけ ればならない。事実 Councilman7) は，身体が水 平なままの入水を望ましくないとしている。

これらの記述にみられる多くの問題点は，一つ 
の研究によって全てが解決される性質のすのとは 思われない。しかし，それに向かって行なわれる 試みが，たとえ小さなものであっても，その価值 を娍ずるものとは言えないであろう。

\section{3. 万 法}

本研究では，初心者における競泳のスタート動 作として最す一般的な方法，即ちスタート台上に 中腰状態で構え, 合四の直後に両腕を後方, 更に 前方に振り出し，その勢いを利用してキックを行 な5とびこみ方を取り上げた．東京学芸大学男女 学生の中からこのスタート法に関して典型的と 思われる熟練者と未熟練者合計 6 名を被験者とし て選び出した。

各被験者について 2 回つつ，実際の競技状況に 模して(クロール), スタート動作を行なわせ, 被 験者の側方から，その演技を高速度映 画に収め た。出発合困には雷管によるピストルを，映画撮 影には地上より $1.10 \mathrm{~m}$ の高さに設置したボレック ス社製16mmカメラと.フシネオパン R250 ポシ フィルムをそれそれ用いた。映画における被験 者の背景に, $2 \mathrm{~m} \times 4 \mathrm{~m}, 10 \mathrm{~cm}$ マスの格子板を 設置して，空間移動距離を測定する基礎とし，ま たボール落し法”によって，カメラのシャッター スピード（毎秒60.0コマと判明）を検定した。

フィルム現像の後, ミニコン付ナックモーショ ンアナライザーを用いて，身体重心や，身体各部 の移動軌跡を記録分析する一方，投影法によって 各コマ画をトレースし，演技のフォームを遂次分 析した。計测に当っては，被験者の基蕉となる部 位にテープを貼付（くるぶし，滕関節の中心，大 転子，肩峰，耳下，时関節，手首）した。なお，同 一被験者について求めた 2 つの結果の5ち, 飛距

Table. 1 Characteristics of the Subjects.

\begin{tabular}{l|c|l|l|l|l}
\hline name & sex & age & height & weight & career \\
\hline A. M. & f & 22 yrs. & $159 \mathrm{~cm}$ & $53.0 \mathrm{~kg}$ & $5 \mathrm{yrs}$ \\
S.A. & f & 20 & 156 & 51.0 & 1 \\
J. I. & $\mathrm{m}$ & 18 & 170 & 55.0 & 8 \\
T. E. & $\mathrm{m}$ & 23 & 172 & 62.0 & 4 \\
T. I. & $\mathrm{m}$ & 20 & 164 & 54.0 & 5 \\
T.S. & $\mathrm{m}$ & 25 & 170 & 72.0 & 6 \\
\hline
\end{tabular}

離の大きかった分を正式データとして採用した。 各被験者の概要を表 1 に，スタート動作の分析 結果について，主要な変量を表 2 に示す。 またス タート動作におけるフォームの変化を追跡すると ともに，各関節角の経時的変化をグラフ化し，各 演技の特質を検討したが，その例を図 1 ～5に示 す.これらをもとにして，以下にスタート動作の 分析結果を考察する.

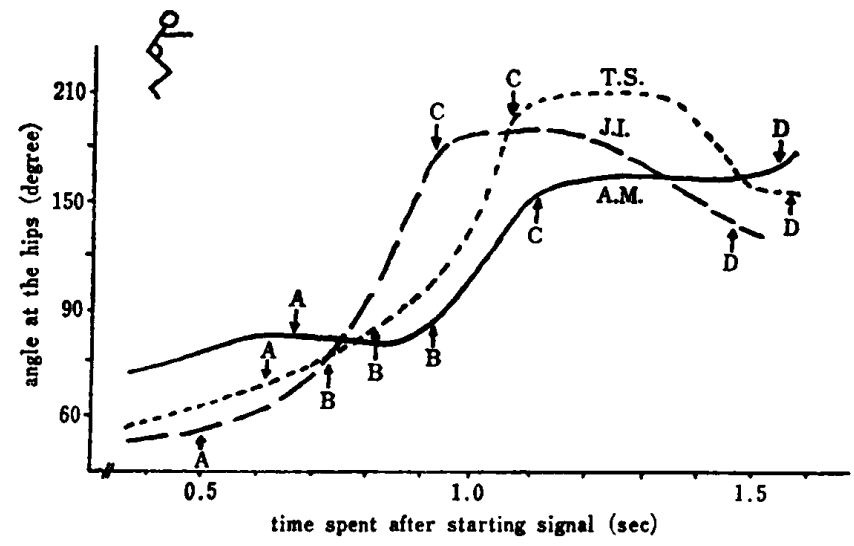

Figure 1. Examples of sequential changes in trunk-thigh angle during the time course of diving action.

A: moment of maximum backward arm swing

B: moment of maximum forward arm swing

C: moment of foot take-off the block

$\mathrm{D}$ : moment of body entry into water

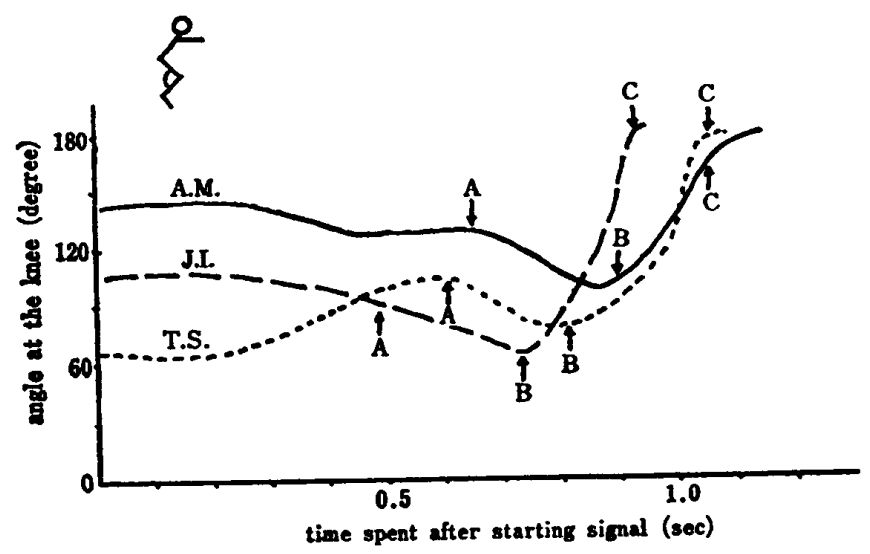

Figure 2. Examples of sequential changes in knee angle during the time course of diving action.
A: moment of maximum backward arm swing

B: moment of maximum forward arm swing

C: moment of foot take-off the block 
Table. 2 Results of Mechanical Analysis of Racing Dive.

\begin{tabular}{l|c|c|c|c|c|c}
\hline Subject & A.M. & S. A. & J. I . & T. E. & T. I. & T.S. \\
\hline at poise & & & & & & \\
CG (center of gravity) height from water (m) & 1.22 & 1.27 & 1.20 & 1.38 & 1.27 & 1.15 \\
CG distance from edge of pool* (m) & -.06 & -.05 & -.06 & -.09 & -.06 & -.12 \\
\hline starting signal-take-off & & & & & & \\
CG height at its lowest moment (m) & 1.16 & .91 & 1.88 & 1.22 & 1.01 & 1.10 \\
CG distance at its lowest moment (m) & .38 & .48 & .23 & .38 & .44 & .30 \\
knee angle when CG lowest (degree) & 90 & 96 & 67 & 83 & 96 & 76 \\
hip angle when CG lowest (degree) & 87 & 90 & 61 & 90 & 102 & 80 \\
time length (sec) & 1.08 & 1.05 & .95 & .93 & .93 & 1.03 \\
\hline take-off-entering water & & & & & & \\
CG initial horizontal velocity (m/sec) & 3.00 & 3.51 & 3.54 & 3.44 & 3.64 & 4.29 \\
leg angle with level at take-off (degree) & 52 & 17 & 35 & 30 & 22 & 26 \\
trunk angle with level at take-off (degree) & 10 & 0 & 16 & 37 & 22 & 26 \\
CG initial flight angle (degree) & 2.4 & -15.1 & 5.1 & 1.9 & 6.5 & 8.8 \\
CG horizontal flight distance (m) & 2.69 & 2.18 & 3.32 & 3.35 & 2.91 & 3.20 \\
CG height at its highest moment (m) & 1.20 & .85 & 1.21 & 1.37 & 1.11 & 1.23 \\
CG distance at its highest moment (m) & .96 & .94 & 1.29 & 1.15 & 1.11 & 1.19 \\
angle of CG projestion into water (degree) & 55.8 & 48.5 & 51.1 & 58.5 & 47.2 & 51.7 \\
angle of thigh against water when entering & 6 & -12 & 32 & 52 & 15 & 5 \\
angle of trunk against water when entering & 10 & 12 & 23 & 5 & 5 & 10 \\
time length (sec) & .54 & .35 & .65 & .68 & .52 & .50 \\
\hline
\end{tabular}

Note: * Positive values in the center of gravity distance from edge of pool indicate distances towards direction of flight.

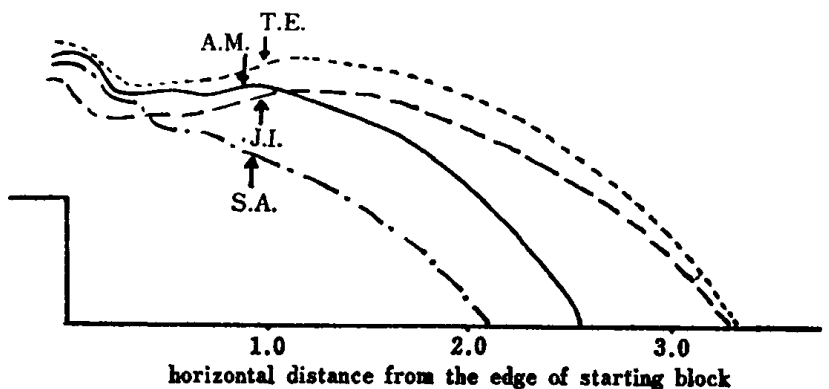

Figure 3. Examples of center of gravity locus duriug the time course of diving action.

Note: mark indicates center of gravity (CG) position at the moment of foot take-off the block.

\begin{tabular}{l|r|r|r|r}
\hline \multicolumn{1}{c|}{ subject } & T. E. & A. M. & J. I. & S. A. \\
\hline $\begin{array}{l}\text { CG distance from edge } \\
\text { of starting block at the } \\
\text { moment of take-off (m) }\end{array}$ & .99 & .89 & .97 & .94 \\
\hline $\begin{array}{l}\text { CG height from water } \\
\text { at the moment of } \\
\text { take-off (m) }\end{array}$ & 1.35 & 1.18 & 1.15 & .85 \\
\hline
\end{tabular}

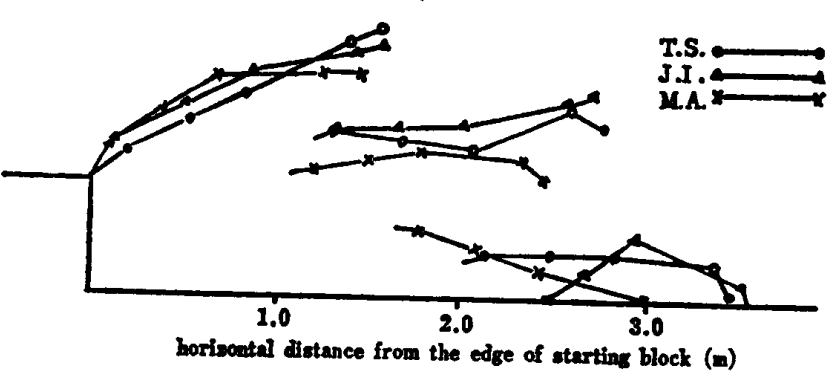

Figure 5. Schematic changes of body form from take-off to the entry into water

\section{4. 桔果と考家}

\section{1.「用意」の姿勢（棈光）}

とびこみ勒作中を通しての，腰部（大腿と体幹 のなす角度，即ち大枟子を基隼として 瞵 関節 中 心，有峰とをそれそれ直線で結んで作られた角 度）及び滕関節（㮏関節中心を基準として，くる ぶしと大転子とで作る角度）における屈伸状態を 


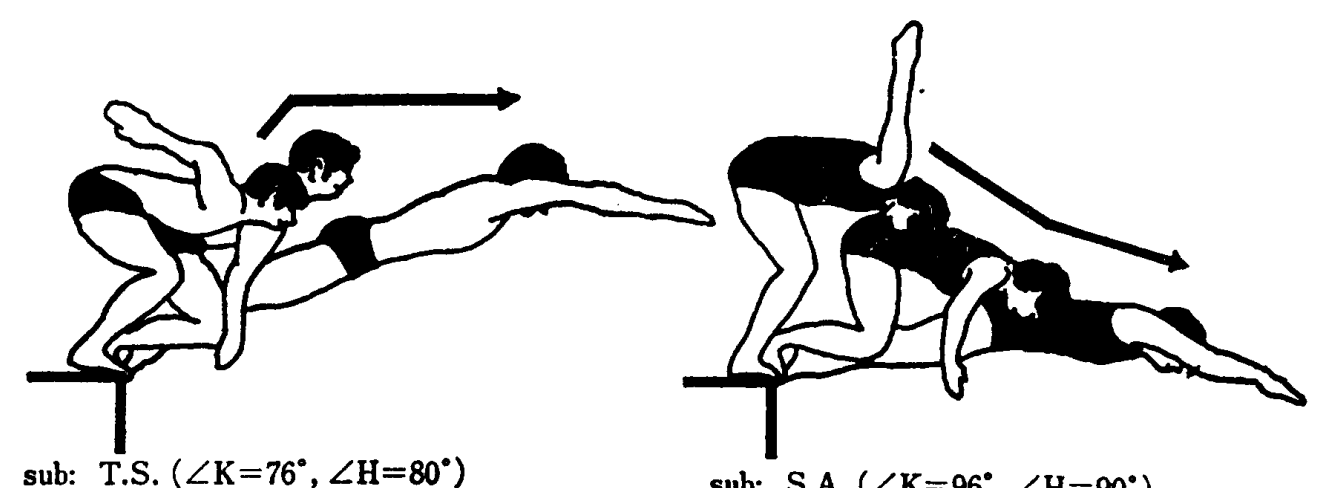

sub: T.S. $\left(\angle \mathrm{K}=76^{\circ}, \angle \mathrm{H}=80^{\circ}\right)$

sub: S.A. $\left(\angle \mathrm{K}=96^{\circ}, \angle \mathrm{H}=90^{\circ}\right)$

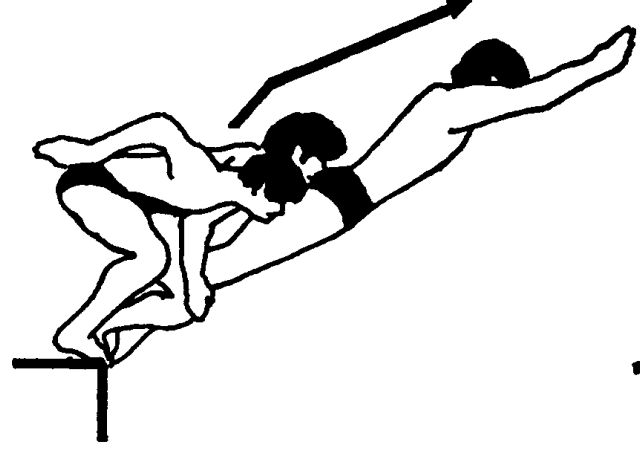

sub: T.E. $\left(\angle K=83^{\circ}, \angle H=90^{\circ}\right)$

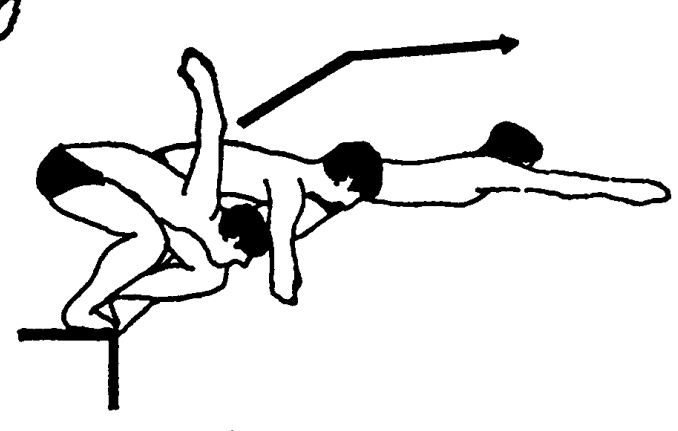

sub: J.I. $\left(\angle \mathrm{K}=67^{\circ}, \angle \mathrm{H}=61^{\circ}\right)$

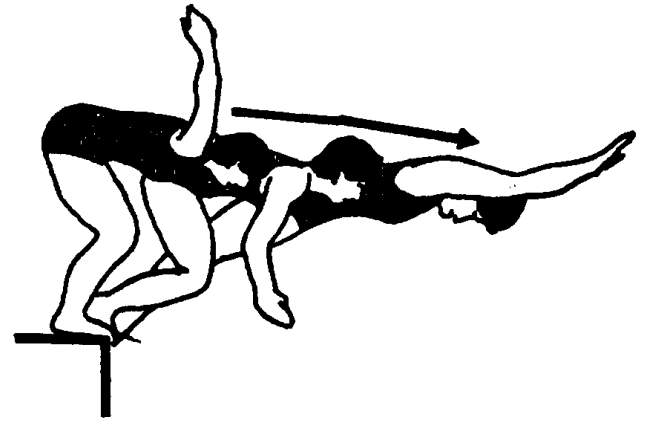

isub: A.M. $\left(\angle \mathrm{K}=90^{\circ}, \angle \mathrm{H}=87^{\circ}\right)$

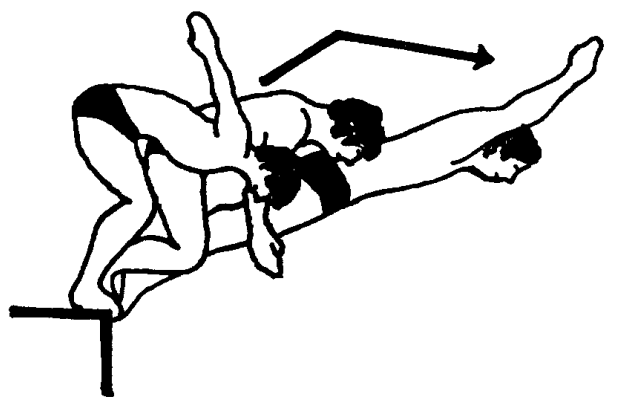

sub: T.I. $\left(\angle \mathrm{K}=96^{\circ}, \angle \mathrm{H}=103^{\circ}\right)$

Figure 4. Sequential drawings from the moment of backward arm swing to the moment of take-off.

Note: $\rightarrow$ indicates movement pattern of the head.

$\angle \mathrm{K}$ indicates the angle at the knee at the moment of maximum knee flexion. $\angle \mathrm{H}$ indicates the angle at the hips at the moment of maximum knee flexion.

調べるために，代表的な被験者について図 1 およ び図 2 をそれそれ作成した。この両図における左 端，即ち時間の 0 点が，「用意」の勢における 中腰の状態を示している。どちらの角度について も個人差が大きいが，いつれれいわゆる中間䝷 をとっていると言えよ5。

「用意」の勢では，重心垂線を基底面前縁に 近く位置させ，それが著しく低くならないように することが，いわゆる重心不安定の状態を作り出 す17と考えてよいだろ5｜また，「スタート」の
合四とともに，瞬間的に全身を伸展し，その伸展 力を足踣，特に踓指部を通じてスタート台前縁お よび前壁上部に作用させ，その反作用として全身 が前方に鋭く発射されることが，この動作の成否 を支配するといえよ5 $5^{7,17) . ~}$

この時，各関節における伸筇群の收樎力が最も 有効に㗢くよ5な関節角にあることが望ましい。 丹羽によれば，最高能率角度には個人差があるこ

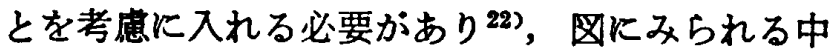
間智勢のとり方の差はその観点から説明可能とも 
言之よう・‥万，関節伯と筋力の関係は，動作が 単関節性であるか䘭関節性であるかによって 異な ることが，波多野によって指摘され(5)，事実， Evertsは，腰部を含めた下肢の伸展においては， 全伸展位に至る直前期に最も有効に力を発現し得 るとしているッ゙.

バレーボールのスパイクにおけるジャソプのた めには, $93^{\circ} \sim 94^{\circ}$ の届腅 25$)$, 走幅跳の踏又切りの 屈滕角は $140^{\circ} \sim 150^{\circ}$ が望ましい28（何れも全伸展 位を $180^{\circ}$ とする.)と言われているが，本研究に見 られるとびこみ势では，腰部及び滕部において 何れも深い届曲度を示している。これは助走を伴 って上方又は前上方を目指すシャンプと，静止時 から前方に向けて行われる瞬間的筋収樎との間に 働くメカニズムに，差異があると考えるべきであ 万5.

図 1 および 2 を吟味すると，グラフにおける曲 楾が交差して，測定対象となった両角度が大きい （伸展位に近い）者ほど，一般的にとび出しまで の所要時間が長い。このことから，水泳における とびこみでは，それが個人差であるか，トレーニ ング効果であるかは別として，腰部や膝関節をあ る程度深く曲げた状態から大きな睜発力を発現で きる者が有利であると考えて良いと思える。

更に，両関節の急激な伸展は「スタート」合図 から0.8〜1.0秒後に行なわれていると言える. 事 実, 各被験者とも完全に足䠕がスタート台を離れ るまでの所要時間は，0.9 1.1 秒程度（図 1，2 におけるC点，表 2 におけるとび出しまでの所要 時間）であり，その間の約 0.2 秒の時間差は, 腰 部および䐒関節が十分に伸展した後に，足首部が 伸展したために生じたと考えられる，例えば，横 山ら ${ }^{283}$ は，走幅跳の踏切において，伸䐂動作の約 0.02 秒後に足首の伸展動作があると埌告してい る.

\section{2. 楎えからとび出しまでの動作}

スタート動作から入水までの，推定重心の移動 軌跡の例を図 3 に示した。これから明らかなよう に，との被験者す「構え」の姿勢から「とび出し」 までの間に，重心が前下方に移勤するのが一般的 である.この時，「とび出し」の瞬間に向って屈 滕度が増大し，また，重心が基底面前縁に近つ
き，後には(「とび出し」の瞬間よりかなり以前 に）基底面外に出てしま うことが演技の条件にな るからである．実，罒2に示したよ5に最大届 滕が成就された睤間からキックが始っている。

さて，ひとたびスタート台を離れてしまった人 体では，（四3におけるよ印より右方）その重心 軌跡が放物線を示すことは当然であるが，それ以 前（よ印より左方）では不規則な曲線が若干みら れる被験者が多い。これが円滑でないということ は，鲸りの力の方向が一定でないことで，スター トに拈ける出力に関して明らかに不利と言える。

最も経跧の浅い被读者 S.A.Kあっては，力強 いキックが働かす゚に，ほとんど前下方に落ちるよ らなスタートになっているので，必ずしも上述の 例に該当するとは言えない。しかし，因3の軌跡 にやや顕著な山凹がみられる被験者 A.M.につい て四1，2．を調べてみると，特に伸䐂動作が段階的 になっていることが分る。この部分は練習によっ て改良が可能な要素といらべきで，S．A．の例と ともに，この動作に関する未熟練が指摘される。

また，重心位四が一度下った後に，S．A．以外 の被験者では，重心動跡が水平方向か，やや前上 方に向っている、これは表 2 における「とび出し」 に打ける体幹と水平軸（X軸）とのなす角度の值 が，全て正の值を示すことに明らかである。この 值が0゚であった唯一の例にあたる S.A．について は，図3の站跡を検討すると，この被験者が十分 にスタート台を押していないことが理解される。

「スタート合四」を認知すると，構えの努勢か ら腕を後方，更に前方に振り出すことが一般的で ある.しかし，最近の競泳界では时を曲げ腕の振 動半径を短かくすることで，とび出しまでの所要 時間を短樎する試みす見られるが，ここではそれ に関する議論を省略するまた，グラブスタート についてる言及しないことにする。

腕の振りは足踫部の受ける作用力を大きくし， 振動による遠心力を前方へ作用させるといら力学 上の利点とともに，身体の飛行方向をコントロー ルし，腰部伸展を觎出する莇きがあると考えられ $3^{1,17,23,24)}$.

さて，四3にみられるように，重心位圆が一度 沈んだ直後に，その䩔跡が直ちに放物線になるわ 
けではない。この部分において，力が直線的に加 わる時間（従って水平距離）が長いことは，水平 速度を大きくするためには有利なことと考兄られ る. 実際の重心移動が放密に水平方向である例は 少ないが，これは最大届㮏時直後に頭部が上方へ 移動する例が多いことを考えれば，むしろ当然で ある。しかし，図4 に2られるよ5に，今回の結 果では，仮りに重心が水平方向に移動してもそれ は短かかったし，実際には指先きからの入水に終 わる傾向がみられた，競泳では指先きからの入水 が望ましくないことは，既に宮下らの指摘すると ころである ${ }^{109}$. 全体的にみて,より有利なとびこみ と考兄られた例では，この時点での直線的重心移 動は，伸䀧，伸腰動作時では水平方向でありなが ら，その最後の局面で足部のスナップによって， これが水平よりやや上方, 即ち図2. にあるよ5 に，足がスタート台を離れる睡間に重心移動にお ける上昇角が $5^{\circ} \sim 10^{\circ}$ に向けられている。この場 合は，放物運動に入る前の重心移動はやや直線的 であり，渐時，放物運動へ之移行して行くのであ る.このことから，放物線に至る出力を決定つけ る主要因は，伸㮏，伸腰動作であり，その放物線 に至るまでの重心上昇角度を微妙にコントロール しているのが足部の底屈動作であると言える。

\section{3. とび出し動作}

競泳におけるとびこみでは，水平に近い角度 で，水平方向に大きな速度を含んだ重心移動が望 まれる ${ }^{18,19,26)}$.この時，スタート台に大きな力を 作用させるが，実際には重心が既に基底面から外 れている。この局面では膝の動きに関心が向けら れる。

とび出しにおける射出角は， S . A .を除けば全 員が $0^{\circ} \sim 10^{\circ}$ の範囲内に収まる。これは，Gray な どの指摘にある原則 ${ }^{11}$ と一致している。例外とな った初心者の S.A.では，この角度がー $15.05^{\circ}$

(マイナスは下向き) であり，飛距離も最小を示 した（表 2，因 3). 同じ女子ではあるが，ょり 大きな飛距離を記録した A.M.は，初速で S . A . に劣り $\left(3.00^{\mathrm{m}} / \mathrm{s}<3.51^{\mathrm{m}} / \mathrm{s}\right)$ ながら，射出解でや や上向き $\left(2.35^{\circ}\right)$, そして飛距離は他の男子被験 者に近かった。、いか水平速度が大きくとも，水 中に入ってその速度を減する時期が早く来て不利
になることが明白である。

とび出しに際して，滕関節が最大届曲角をなす 時期を調へると（例を図 2 ，に示す），その時に重 心がスタート台の近くにある者と迺くにある者が ある．前者では，体が自然落下しにくく，従って， キックのタイミングを取り易いと考えられる。そ れに対して後者では，キック動作において下腿が 前傾し，体は回転を始めているので，キックのタ イミングが不安定になるようにみえる。これは頭 部の移動パターンが下向きになっている（四4; S.A., A.M., T.I.)ことや，とび出し直前 における重心の不規則な上下動（四 $3 ;$ ：S．A.,A. M.)などからも5かがえる.

4.4. 入水直前

とび出しから入水までの間の各被験者の智を 追跡し，数例を模式化（蹠指部先端，〈るふし， 㮏関節中心，大伝子，眉峰，耳下をそれぞれ直線 で結んだ）し因5に示したＴ．S．についてみる と, 中間期において頭部が下降し，入水に至るま での間に，特に下半身に打ける相対動作の起る余 地が少ないことが理解される，一方，J．Ｉ．では とび出し直後に頭部が著しく上向きとなり, 入水 に近つくにつれ頭が下がる，相対動作としての下 半身の下降がこの時にみられる。また，とび出し 直後における足先位置が重心よりも低く，体の前 方回轱す起きていない.このままでは足先が先に 入水することが予想されるが，それを補曊するた めに，上半身を沈めて頭から入水する(シャック ナイフ型) 形をとっていると考えられる（例えば 田 5 ).

入水時に届腰しては不利だと言われるが日 ，こ れを防ぐためには，とび出し直後に足先が重心位 置を著しく下まわってはいけないといえる.キッ クの出力が同じであるとすれば，これを体の前方 回転力に使用することは, 重心の水平移動のエネ ルギーを娍ずることになり，不利であろう， A． M.はその例に当る.

空中で体を伸展させると，前の前方回転をコン トロールする作用が生じ，またそれによって体を 水平に保って入水することが可能であると言 $5^{27)}$.しかし，四5 にみられるよ5に，空中で体 が過伸展している例がある（J.I., T.S.）が，それ 
は必ずしま入水時の水平智を保障するわけでは ない。例えば J ．I．では用腰姿勢で入水している が，これは空中における体の過伸展が不足したた めかとも思われる。

本研究の結果からは，必ずしも効率の商いとび こみ法を求めることは出来ない。むしろここにあ げた数例のとびこみ動作の分析は，それぞれ改良 すべき局面を持っていると言えるが，そのような 事例を重ねて行く中で始めてとびこみの理想像が 浮ひ上って来るものであろ5。本研究では，指導 上有効と思われる $2 ， 3$ の原則が結語として指摘 されるに止まった。

\section{5. 結 語}

競泳のスタート動作としてのとびこみについて 映画分析を試み，与えられた数例について吟味を 進めた。 とびこみの初期勘作から入水に至るま で，各人各様の技のこなし方を持っていることは 明らかであるが，それらを検討する道程におい て，指導上有効と思われる原則がいくつか導き出 された。

1. 構えの姿勢では, 重心を比較的高く保持 し，しかるそれをスタート台前縁に近つける ことが有利である。

2. とび出しでは，㮏関節を最大に届曲する時 点においては，重心線がスタート台前縁近く に位置することが勧められる。

3.この時, 滕, 腰両部を深く届曲した状態か ら，瞬間的に大きな伸展動作ができる能力を 持つことが有利と考えられる。

4. 水平よりる僅かに上向きが望ましいとされ ているとび出しの方向を決定づける 主要因子 は，伸睩・伸腰動作であるが，足首のスナッ プあコントロールに与かっている.

5. とび出した直後の空中努勢においては，体 を過伸展することにより，入水時に体の直線 性が得られるならば，これは差支えない。

\section{引用 文献}

1）アムブルスター, D. H., R.H. アレン, H.S.ビリン グスレイ (江橋・宮下訳)，水泳教程，ベースボール マガジン社, 1975. pp. 55〜68.
2) Amateur Swimming Association, The Teaching of Swimming, The Devonshire Press, 1919. pp. $148 \sim 154$.

3) Bunn, John W., Scientific Principles of Coaching, Prentice-Hall, Inc., 1955. pp. 106 107 and 183 84

4）調枝孝治, タイミングの心理, 不昧堂, 1972. pp. 93 95 .

5) Cureton, Thomas Kirk, "Elementary Principles and Techniques of Cinematographical Analysis as .Aids in Athletic (Research," ${ }_{L}$ Research Quarterly, $10: 3 \sim 24,1939$.

6) Cooper, J.m. and R.B. Glassow, Kinesiology, C.V. Mosby, 1963. pp. 159 62.

7 ) Councilman, J.E., The Science of Swimming, Prentice-Hall, Inc., 1968. pp. 133 42.

8) Elkington, H. and T. Holmyard, Better Swimming for Boys and girls, Kaye Ward, Ltd., 1967. pp. $15 \sim 18$.

9) Everts, C.R. and G.J. Hathaway, "The Use of Belt to Measure Leg Strength Improves the Administration of Physical Fitness," Research Quarterly, $9: 62 \sim 69,1938$.

10）古橋広之進, 宮下充正，スポーッの科学的指道面， 水泳，不昧堂, 1973. pp. 206 12.

11) Gray, A.W., "The Racing Dive," Scholastic Coach, $3:$ 23 25, December, 1934.

12) Groves, W. H., "Mechanical Analysis of Diving," Research Quarterly, 21 1: 132 44, 1950.

13）グールド，C.（宮川僐訳)、シェーングールドの泳 法, ベースボールマガシン社, 1973. pp. 34〜36.

14) Harlan, B. and D.H. Robertson, Competitive Swimming, Sterling Publishing Co., 1963. pp. $11 \sim 18$.

15）波多野郎，「ケーブルテンシオメター使用による 各種筋力測定の結果比つて」体育学研究, 17〜2： 89〜95, 1972.

16）池内八郎，「競泳のスタート動作阅する分析的研 究」体育学研究, 13 5: 171， 1969.

17）ジェンセン, C.R., G.W. シュルッ（波多野・小林 訳), スポーツ動作の科学的分析, 泰流社, 1977. pp. $270 \sim 71$.

18）宮畑虎彦，杵㴊政光，水泳，不昧堂，1972. pp. 128 31. 
19）宮下充正ほか，競泳のコーチング，大修館書店， pp. $101 \sim 103$.

20) Maglischo, C.W. and E. Maglischo, "Comparison of Three Racing Starts used in Competitive Swimming," Research Quarterly, 39 3 : 604 $09,1968$.

21）日本水泳連盟普及委員会，水泳指望，文教蓄院， 1976. pp. $217 \sim 27$.

22）丹羽昇，「関節角度から見大脚筋力」体骨学研究， $9 \sim 1: 173,1967$.

23）涉川㑆二，春山国広，三浦望度，「身体, 脚部の力 学的性和にいて」東京教育大学体育学部スポーツ研 究所報，4:51〜 58, 1966.

24) ，吉本修，「垂直跳の力学（第 2 報）」東京
教育大学体育学部スポーツ研究所報, $7: 47 \sim 54$, 1969.

25）豊田博，「バレーボールのジャンプK関する研究」 もっとも新しいバレーボール，日本文化出版，1973. pp. $228 \sim 33$.

26）梅田利兵衛, 宮畑虎彦, 水泳, 学芸出版, 1961 . pp. $152 \sim 62$.

27）山根成之，「水泳の逆飛込みにおける動作分析につ いて」体育学研究, 9〜1:270, 1964.

28) Yokoyama, Masahiko and Yoshiro Hatano, "Analysis of Take-off Action in Long Jump with Medium Velocity Approaching Run," Japanese Journal of Physical Education, $21 \sim 6$ : 325 34, 1977. 